\title{
Papers
}

\section{A study of the effects of corruption on variance of realised returns}

\author{
Nigel Yin \\ Liautaud Graduate School of Business, University of Illinois at Chicago, Chicago, IL, USA. \\ E-mail: nyin@uic.edu
}

Received (in revised form): 4th March, 2008

Nigel Yin graduated Summa Cum Laude from Southern Illinois University in Carbondale in 2007, specialising in financial institutions. He is currently in the MBA programme at the University of Illinois at Chicago, specialising in finance.

\section{Practical applications}

This paper uses corruption to explain the varying levels of volatility in global financial markets. Corruption is found to be significantly correlated with volatility. This finding has many implications for businesses, financial institutions, and investors who venture into global markets as this gives analysts another tool to gauge volatility in countries and assess risk for pricing securities. In analysis of newly formed financial markets and markets without reliable information, this tool can help assess market volatility. In turn, this will help predict a beta to properly gauge the appropriate returns for the systematic risk inherent in the financial market. This will determine if any security is overpriced or undervalued.

\section{Abstract}

In this study, we argue that volatility in a country's financial market depends on the country's level of corruption. We postulate that countries with higher corruption will experience a larger standard deviation of returns. We also assume that within the same time-frame those less corrupt countries will experience a lower standard deviation of returns from their financial markets. The paper presented empirical results to support our hypothesis.

Journal of Derivatives \& Hedge Funds (2008) 14, 2-8. doi:10.1057/jdhf.2008.2

Keywords: corruption; foreign financial market; volatility; variance; investment

\section{INTRODUCTION}

Corruption has been recognised to be a detriment in organisations of commerce, academics, and government because their systems are conducting its tasks in a fashion that is incongruent with the organisation's intended purpose. And when the absence of integrity shapes ethics, we find that this tentative relationship has a significant impact on the financial markets and renders them susceptible to increased volatility. (In certain studies, however, corruption has been recognised as beneficial to activity systems because it 'greases the wheels' to promote action.)

Corruption has been extensively investigated by academia and business practitioners and has
Journal of Derivatives \& Hedge Funds, Vol. 14 No. 1, 2008 pp. 2-8 (C) 2008 Palgrave Macmillan Ltd $1753-9641 \$ 30.00$ 
been examined in relation to many factors of commerce:

- Currency. Perceptions of corruption in counties (like South Korea and Thailand in 1997-1998) deteriorated along with their currencies in the wake of the financial crisis. ${ }^{1}$

- GDP. The World Bank estimates that as much as $\$ 1.5$ trillion disappears in bribes each year, ${ }^{2}$ shaving up to 5 per cent off annual GDP. And some studies have shown that one standard deviation increase in the corruption index is associated with a decrease in investment of 2.46 percentage points, which in turn decreases economic growth by 0.34 per cent per year. ${ }^{3}$

- Inequality. Corruption and income equality has a significant relationship. ${ }^{4}$

- Productivity. Corruption has been associated with slower productivity growth. ${ }^{5,6}$

- Foreign investment. Corruption in linked with lower levels of foreign direct investment. ${ }^{7}$

- Lower stock capitalisation/undervaluation of publicly traded equity securities. ${ }^{8}$

The purpose of this paper is to investigate the relationship between corruption and volatility of financial markets. The understanding of the underlying relationship will facilitate financial analysts to assess investment risk of foreign countries and make investment decisions accordingly.

The statistical analysis supports our hypothesis with a $p$-value of 7.14365E-05.

\section{REVIEW OF THEORETICAL FOUNDATION}

\section{Corruption}

Merriam Webster's dictionary defines corruption as 'an impairment of integrity, virtue or moral principle,' or in more specific cases in regards to transactions, 'the inducement to wrong by improper or unlawful means'?

Corruption has many meanings to researchers in different fields and varies in context.

Sociologists view corruption as an effective way for organised crime to establish itself in the social system. ${ }^{10}$ Corruption has also been studied extensively by sociologists for possible causes and subsequently correlated with cultural factors such as power distance, masculinity, and individualism. ${ }^{5}$ Political scientists examined corruption in relation with democracy and campaign finance. ${ }^{11}$ Economists saw corruption as detrimental to economic growth, ${ }^{5,6}$ while others contradict the popular sentiment and studied corruption as a form of cooperation that 'greases the wheels' of commerce. ${ }^{12,13}$

Corruption has been viewed as culturally relative. While gift-giving and favour exchanges were considered social norms in Chinese studies, ${ }^{14}$ these acts are labelled as bribery and corruption in Western studies. ${ }^{5,6}$ The field of economics also resulted in studies and theoretical models of game theory, ${ }^{15}$ principal-agent model, ${ }^{16}$ Cobb-Douglass production function, ${ }^{17,18}$ and rent-seeking theory. ${ }^{19,20}$

In this paper, the construct of corruption was defined and addressed in the context of economic transactions. The Alemann ${ }^{21}$ definition is as follows:

Corruption is always an exchange process between two or more persons (or groups organised into two or more parties). The person who corrupts is in possession of economic goods or resources that are scarce; the person who is to be corrupted possesses power in its broadest sense - power that was transferred to him or her by a defined public body to be used for the common good and according to fixed rules. The 
person who corrupts wants to get a concession or a contract or wants to avoid a punishment. He or she therefore bribes the person to be corrupted, that is, the person who has the power to issue to concessions or decide otherwise. It is, however, also possible that the person to be corrupted takes the initiative, making further demands on the person corrupting him or her.

\section{Market volatility}

Volatility is defined as characterised by or subject to rapid or unexpected change. Volatility in finance terms is quantified by the standard deviation of the percentage change in price of a security. Volatility is commonly categorised as either diversifiable (nonsystematic/security risk) or nondiversifiable (systematic/market risk) in terms of change in value of a financial instrument or returns of financial markets, respectively.

It is also categorised by time reference. Historical/ex post volatility is volatility of a security measured from past returns. This is opposed to current/ex ante volatility implied by the market measured by expected volatility in the market such as the VIX (Chicago Board Options Exchange's volatility index, which is the investor's prediction of near-term market volatility).

Volatility is commonly calculated in comparison to financial markets by using regression analysis to form Beta. It is this volatility that is basis of many stock valuation models, such as the Capital Asset Pricing Model, which determines the appropriate rate of return and thus can be used to value securities. The future cash flows from the security can be discounted with the expected return and thus can determine if the security is under or overvalued. Jack Treynor, ${ }^{22}$ William Sharpe, ${ }^{23}$
John Lintner, ${ }^{24}$ and Jan Mossin ${ }^{25}$ were quick to realise the implications of accounting for volatility for rating various investments.

For the purposes of this paper, volatility is defined as ex post, market-wide variance of market indices.

\section{HYPOTHESIS}

Volatility goes hand-in-hand with rent-seeking activity. Recent events such as the Enron scandal, which reduced the stock priced around 90 dollars to pennies, caused the dissolution of Arthur Andersen, which led to the loss of 28,000 jobs in the US and 85,000 worldwide. Other incidents include Adelphia Communication's embezzlement, Exxon's overreporting of oil reserves, Halliburton's overcharging, Lockheed's bribes, Xerox's and KPMG's accounting, TYCO's embezzlement, BAE's scandal, BREX's scandal, Deutsche Borse's Clearstream, etc.

Corruption is even more present globally ${ }^{26}$ with more widespread influence in developing countries with emerging economies.

Corruption has been extensively studied in economies such as Russia, ${ }^{27}$ Mexico, ${ }^{28,29}$ Thailand, ${ }^{30}$ Indonesia, ${ }^{20}$ and China. ${ }^{31}$

Surprisingly, reports revealed that efforts to reduce corruption can also increase volatility. Cracking down on corruption resulted in falling markets in Bangladesh. ${ }^{32}$ Taiwan also experienced similar effects. ${ }^{33}$

Recently, with the rise of ETF (electronically traded funds), which track foreign markets, and ADR (American depository receipts) foreign investment has become more popular with investors with 13 per cent of Americans with international stocks in 2007 and an increase to 19 per cent in the next five years. ${ }^{34}$ US mutual 
funds also invested 22 per cent of assets in world funds. ${ }^{34}$ It would seem prudent to valuate the nondiversifiable risk inherent in these investments with corruption as they are subject to rapid or unexpected change.

Investors require compensation for the risk they bear. If investments in a foreign market index fund outperform a domestic index fund but has considerably more risk, the valuation of this investment should have realised returns adjusted for volatility in order to compare them meaningfully. Thus, we propose the following hypothesis:

Countries with high levels of corruption will experience a larger variance of return in their financial markets and countries with low levels of corruption will experience a lower variance of return.

\section{FRAMEWORK AND VARIABLE MEASUREMENT}

\section{Independent variable - Corruption}

The independent variable measured by the Corruption Perception Index (CPI) published by Transparency International was used in this study. This index is a composite index that draws from 12 different surveys conducted by nine independent institutions (such as the World Bank and United Nations) and covers 163 countries. The countries included in the index must have scores from at least three sources. This index is the most complete and has the greatest scope of any index to date. ${ }^{35}$ The scores of the index range from zero to ten (with zero indicating the highest level of perceived

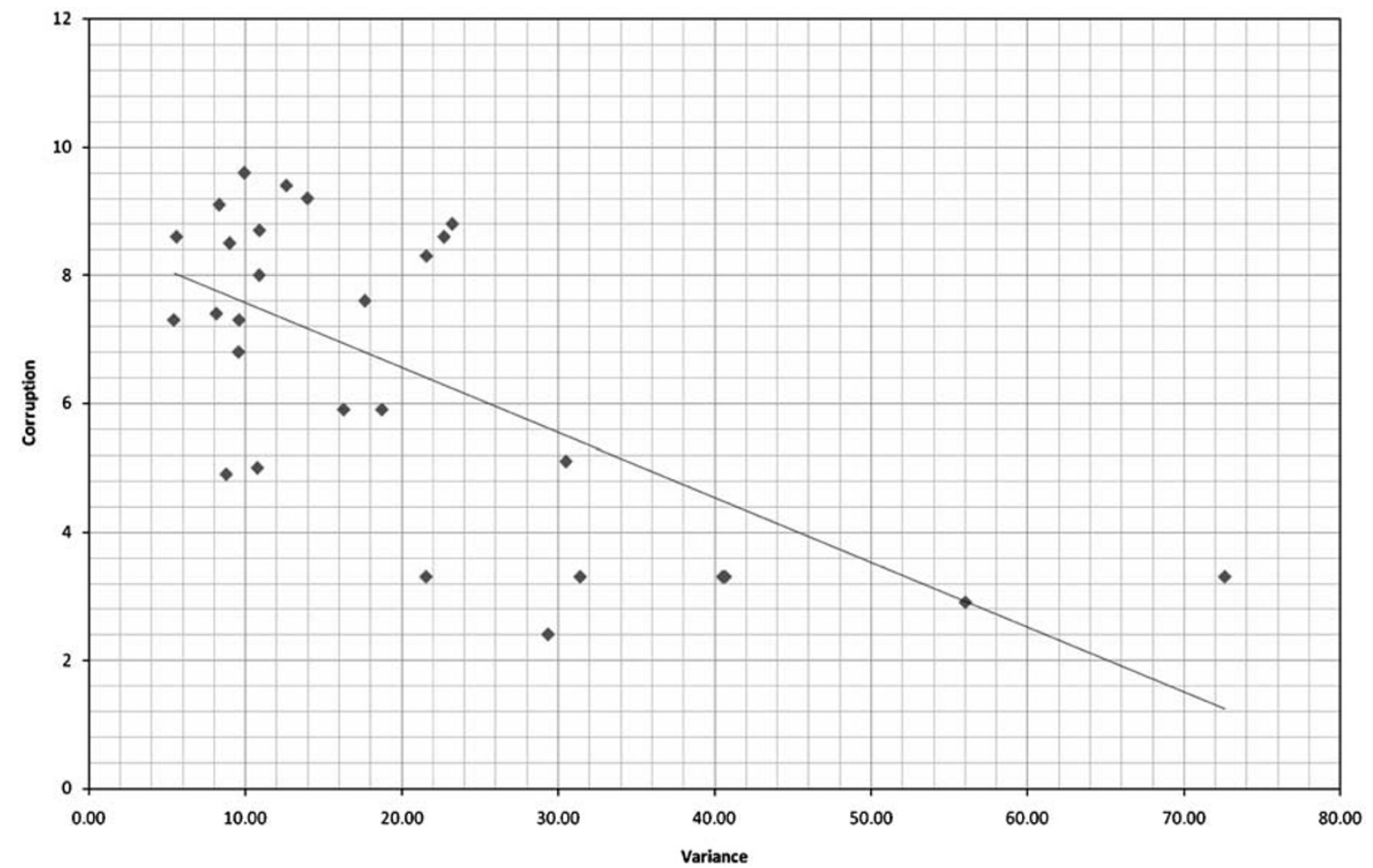

Figure 1: Distribution diagram of variance and corruption of 28 countries. 
Table 1: Coefficients ${ }^{a}$

\begin{tabular}{lllllll}
\hline & \multicolumn{2}{l}{ Unstandardised coefficients } & & \multicolumn{2}{l}{ Standardised coefficients } \\
\cline { 2 - 3 } Model & $B$ & Std. error & & Beta & $t$ & Sig. \\
\hline Constant $)$ & 0.005 & 0.001 & & & 7.519 & 0.000 \\
COR & 0.000 & 0.000 & & -0.679 & -4.714 & 0.000 \\
\hline
\end{tabular}

${ }^{\mathrm{a} D e p e n d e n t ~ v a r i a b l e: ~ V A R . ~}$

Table 2: Analysis of variance ${ }^{a}-$ Decomposition of sums of squares

\begin{tabular}{lccccl}
\hline Model & Sum of squares & DF & Mean square & $F$ & Sig. \\
\hline Regression & 70.21663542 & 1 & 70.21663542 & 22.22534079 & $7.14355 \mathrm{E}-05$ \\
Residual & 82.14193601 & 26 & 3.159305231 & & \\
Total & 152.3585714 & 27 & & & \\
\hline
\end{tabular}

${ }^{\mathrm{a}}$ Dependent variable: VAR; Predictors: COR.

corruption ten and indicating the lower level of perceived corruption).

\section{Dependent variable - Market volatility}

In our study, historical market volatility was treated as the dependent variable. It was measured as the variance in the percentage change of the indices of the markets of 28 countries (S\&P 500, Nikkei 225, DAX to name a few). The monthly adjusted closes data were extracted from Yahoo finance database's historical prices. The variations of the indices were recorded from 1st November, 2007 to 1st April, 2004 (this was due to New Zealand's NZX 50 short history). The monthly adjusted closes were then adjusted to percentages using monthly holding period returns $((\mathrm{Pn}+1 / \mathrm{Pn}) /$ $\mathrm{Pn})$. The percentages were changed from decimals to whole numbers (eg 5.15 instead of
0.0515). Finally, variance was calculated for each index's returns and a regression was run on the countries' variance and respective corruption index.

\section{Analysis}

The results were subjected to ANOVA and regression analysis. Tables 1 and 2 show the results of the analysis. The $F$ value is significant with $p$-value at 0.000 (Figure 1).

\section{CONCLUSION}

The social and economic cost of corruption has drawn significant attention from government, business, and academia. Research efforts have been emphasising the effects of corruption on investment and economic growth. No attempt has been made, however, to elaborate the impact 
of corruption on market volatility. This article used corruption to explain the varying levels of volatility in global financial markets. Corruption is found to be significantly correlated with volatility. This finding has many implications for businesses, financial institutions, and investors who venture into global markets, as it gives analysts another tool to gauge volatility in countries and assess risk for pricing securities.

\section{References}

1 Economist (2006) 'Strains of Sleaze', Economist, Vol. 381, No. 8503, p. 69.

2 Litvack, K. (2006) 'Emerging Markets Clean Up Their Act', Euromone, Vol. 34, No. 442, pp. 158-160.

3 Pellegrini, L. and Gerlagh, R. (2004) 'Corruption's Effect on Growth and its Transmission Channels', Kyklos, Vol. 57, No. 3, pp. 429-456.

4 Jong-Sung, Y. and Khagram, S. (2005) 'A Comparative Study of Inequality and Corruption', American Sociological Review, Vol. 70, No. 1, pp. 136-157.

5 Husted, B.W. (2005) 'Culture and Ecology: A Crossnational Study of the Determinants of Environmental Sustainability', Management International Review, Vol. 45, No. 3, pp. 349-371.

6 Soon, L. (2006) 'Macro-economic Outcomes of Corruption: A Longitudinal Empirical Study', Singapore Management Review, Vol. 28, No. 1, pp. 63-72.

7 Zhao, J., Kim, S. and Du, J. (2003) 'The Impact of Corruption and Transparency on Foreign Direct Investment: An Empirical Analysis', Management International Review, Vol. 43, No. 1, pp. 41-62.

8 Khumawala, S. and Ramchand, L. (2005) 'Country Level Corruption and Frequency of Issue in the U.S. Market', Journal of Public Budgeting, Accounting \& Financial Management, Vol. 17, No. 3, pp. 341-364.

9 Webster (2007) 'Corruption', In Merriam Webster [Web]. Retrieved 18th November, 2007, from http:// www.m-w.com/dictionary/corruption.

10 Merton, R.K. (1968) 'Social Theory and Social Structure', Free Press, New York.

11 Hohenstein, K.A. (2004) 'Coining Corruption: Deliberative Democracy, the Constitution, and the Making of the American Campaign Finance System, 1876-1976, Doctorial dissertation, University of Virginia. Order No. DA3131395.

12 Argandona, A. (2005) 'Corruption and Companies: The Use of Facilitating Payments', Journal of Business Ethics, Vol. 60, No. 3, pp. 251-264.
13 Leff, N.H. (1964) 'Economic Development Through Bureaucratic Corruption', American Behavioral Scientist, Vol. 8, No. 3, pp. 8-14.

14 Sun, Y. (2001) 'The Politics of Conceptualizing Corruption in reform China', Crime, Law and Social Change, Vol. 35, No. 3, pp. 245-269.

15 Svejnar, J. and Smith, S.C. (1984) 'The Economics of Join Ventures in Less Developed Countries', Quarterly Journal of Economics, Vol. 99, No. 1, pp. 149-167.

16 Kiser, E. and Tong, X. (1992) 'Determinants of the Amount and Type of Corruption in State Fiscal Bureaucracies: An Analysis of Late Imperial China', Comparative Political Studies, Vol. 25, No. 3, pp. 200-331.

17 Mankiw, N.G., Romer, D. and Weil, D.N. (1992) 'A Contribution to the Empirics of Economic Growth', Quarterly Journal of Economics, Vol. 107, No. 2, pp. 407-437.

18 Everhart, S., Martinez-Vazquez, J. and McNab, R. (2003) 'Corruption, Investment and Growth in Developing Countries', National Tax Association Tax Institute of America, Proceedings of the Annual Conference on Taxation, pp. 84-90.

19 Lambsdorff, J. (2002) 'Corruption and Rent-seeking', Public Choice, Vol. 113, No. 1-2, pp. 97-125.

20 Kuncoro, A. (2006) 'Corruption and Business Uncertainty in Indonesia', ASEAN Economic Bulletin, Vol. 23, No. 1, pp. 11-30.

21 Alemann, U. (2004) 'The Unknown Depths of Political Theory: The Case for Multidimensional Concept of Corruption', Crime, Law and Social Change, Vol. 42, No. 1, pp. 25-34.

22 Treynor, J. (1961) 'Market Value, Time, and Risk', Unpublished manuscript.

23 Sharpe, W. (1964) 'Capital Asset Prices: A Theory of Market Equilibrium Under Conditions of Risk', Journal of Finance, Vol. 19, No. 3, pp. 425-442.

24 Lintner, J. (1965) 'The Valuation of Risk Assets and the Selection of Risky Investments in Stock Portfolios and Capital Budgets', Review of Economics and Statistics, Vol. 47, No. 1, pp. 13-37.

25 Mossin, J. (1966) 'Equilibrium in a Capital Asset Market', Econometrica, Vol. 34, No. 4, pp. 768-783.

26 Ali, A. and Isse, H. (2003) 'Determinants of Economic Corruption: A Cross-country Comparison', Cato Journal, Vol. 22, No. 3, pp. 449-466.

27 Kaufmann, D. and Siegelbaum, P. (1997) 'Privatization and Corruption in Transition Economies', Journal of International Affairs, Vol. 50, No. 2, pp. 419-458.

28 Husted, B.W. (1993) 'Law and Industrial Buyer Seller Relationships: The Privatization of a Mexican Stateowned Steel Company', The International Executive, Vol. 35, No. 3, pp. 199-209. 
29 Husted, B.W. and Serrano, C. (2002) 'Corporate Governance in Mexico', Journal of Business Ethics, Vol. 37, No. (3), pp. 337-348.

30 Emerging Markets Monitor (2005) 'Thailand: Politics Keeps us Bearish', Emerging markets monitor, Vol. 11, No. 32, p. 11.

31 Gong, T. (2003) 'More than Mere Words, Less than Hard Law: A Rhetorical Analysis of China's Anti-corruption Policy', Public Administration Quarterly, Vol. 27, No. 1/2, pp. 159-187.
32 Emerging Markets Monitor (2005) 'Bangladesh: Corruption Crackdown Hurting Stocks', Emerging markets monitor, Vol. 12, No. 47, p. 13.

33 Emerging Markets Monitor (2005) 'Taiwan Stocks: Economics vs. Politics', Emerging markets monitor, Vol. 11, No. 32, p. 13.

34 Salisbury, I. (2007) 'How Much to Invest Overseas', Wall Street Journal, Vol. 250, No. 17, p. B2.

35 World Bank (n.d.). 'Sanctions Committee Procedure. Retrieved 3rd May, 2007 from, http:// go.worldbank.org/BJ9P6TARY1. 